Chirurgia (2019) 114: 602-610

No. 5, September - October

Copyright@ Celsius

http://dx.doi.org/10.21614/chirurgia.114.5.602

\title{
Postoperative Hypoparathyroidism in Patients After Total Thyroidectomy - Experience of a Tertiary Center in Romania
}

\author{
Sorina Martin ${ }^{1,2}$, Ovidiu Parfeni' ${ }^{2}$ Theodor Mustata ${ }^{2}$, Marian Andrei ${ }^{3}$, Anca Sirbu ${ }^{1,2}$, Carmen Barbu ${ }^{1,2}$, \\ Octavian Enciu ${ }^{4,5}$, Florin Andrei ${ }^{6}$, Simona Fica ${ }^{1,2}$
}

\author{
'Endocrinology Department, Carol Davila University of Medicine and Pharmacy, Bucharest, Romania \\ ${ }^{2}$ Endocrinology Department, Elias University Emergency Hospital, Bucharest, Romania \\ ${ }^{3}$ Carol Davila University of Medicine and Pharmacy, Bucharest, Romania \\ ${ }^{4}$ Surgery Department, Carol Davila University of Medicine and Pharmacy, Bucharest, Romania \\ ${ }^{5}$ Surgery Department, Elias University Emergency Hospital Bucharest, Romania \\ ${ }^{6}$ Pathology Department, Elias University Emergency Hospital Bucharest, Romania
}

Corresponding author:

Octavian Enciu, MD

Elias University Emergency Hospital

Blvd. Mărăști nr. 17, Sector 1

Bucharest, Romania

E-mail: esoctavian@gmail.com

\section{Rezumat \\ Hipoparatiroidismul postoperator la pacienții cu tiroidectomie totală - experienta unui centru tertiar din România}

Introducere: Hipoparatiroidismul postoperator (PoSH) reprezintă o complicație cronică, frecventă, a tiroidectomiei totale. Mediana (interval) incidenței PoSH tranzitor şi permanent a fost raportată a fi $27 \%(19-38 \%)$ si respectiv $1 \%(0-3 \%)$.

Material şi Metodă: Am analizat retrospectiv foile de observație a 552 de pacienți supuşi intervenției de tiroidectomie, în departamentului nostru de chirurgie, în perioada 2015-2017, cu scopul de a evalua prevalența PoSH şi a identifica factorii ce țin de pacient şi boală, asociați cu hipocalcemia postoperatorie.

Rezultate: 171 (30.97\%) de pacienți au dezvoltat PoSH, 88.37\% tranzitor, $11.63 \%$ permanent. Mediana (IQR) duratei hipocalcemiei postoperatorii a fost de 60 (67.5) de zile. Parametrii biologici preoperatori au fost similari în lotul PoSH şilotul martor, exceptând mediana nivelului magneziului sericcare a fost semnificativ mai mare în lotul cu PoSH [2.04 (0.17) vs. $1.89(0.28) \mathrm{mg} / \mathrm{dl}, \mathrm{p}=0.005]$. In cazul pacienților $\mathrm{cu}$ carcinom tiroidiandurata intervenției chirurgicale a fost semnificativ mai mare la pacienții cu PoSH comparativ cu lotul martor [135 (60) vs. 110 (43) minute, $\mathrm{p}=0.020$ ]. La pacientii cu PoSH, mediana calciului seric postoperatora fost semnificativ mai mare în cazul pacienților pentru care intervenția chirurgicală a fost raportată ca dificilă $[8.2(0.2)$ vs. $7.9(0.6) \mathrm{mg} / \mathrm{dl}$, 
$\mathrm{p}=0.043$ ] şimedia declinului calciului serica fost semnificativ mai marela pacienții cu disecție centrală a gâtului şi limfadenectomie ( $1.94 \pm 0.59$ vs. $1.68 \pm 0.56 \mathrm{mg} / \mathrm{dl}, \mathrm{p}=0.033)$.

Concluzii: Datele noastre indică o prevalență mare a PoSH, care este posibil să crească avand in vedere creşterea numărului de tiroidectomii efectuate.Cercetări suplimentare sunt necesare pentru a defini mai bine boala şi a stabili tratamentul şi măsurile preventive adecvate.

Cuvinte cheie: hipoparatiroidism, tiroidectomie, hipocalcemie

\section{Abstract}

Background: Post-surgical hypoparathyroidism (PoSH) is a common long-term complication after thyroid surgery. The reported median (range) incidence rates of temporary and permanent PoSH was $27 \%(19-38 \%)$ and $1 \%(0-3 \%)$ respectively.

Material and Methods: We retrospectively analyzed the files of 552 patients who underwent thyroidectomy in our surgery department between 2015- 2017 with the aim to assess the prevalence of PoSH and to identify patient and disease related factors associated with postoperative hypocalcemia.

Results: 171 (30.97\%) patients developed PoSH, 88.37\% transient, 11.63\% permanent. The median (IQR) duration of postoperative hypocalcemia was 60 (67.5) days. Preoperative biological parameters were similar in PoSH and the control group, except median (IQR) serum magnesium level that was significantly higher in PoSH group [2.04 (0.17) vs. $1.89(0.28) \mathrm{mg} / \mathrm{dl}, \mathrm{p}=0.005]$. In the subgroup of patients with thyroid carcinoma the surgery duration was longer in PoSH patients compared to the control group [135 (60) vs. 110 (43) minutes, p=0.020]. In patients with PoSH, median post-operative serum calcium was significantly higher in patients with reported difficult surgery [8.2 (0.2) vs. $7.9(0.6) \mathrm{mg} / \mathrm{dl}, \mathrm{p}=0.043]$ and the mean serum calcium decrease was higher in patients with cervical neck dissection and lymphadenectomy $(1.94 \pm 0.59$ vs. $1.68 \pm 0.56 \mathrm{mg} / \mathrm{dl}$, $\mathrm{p}=0.033)$.

Conclusions: Our data show a high prevalence of PoSH that is likely to increase given the rising number of thyroid surgeries being performed. Further research is needed in order to better define this condition, to establish appropriate treatment and preventive measures.

Key words: hypoparathyroidism, thyroidectomy, hypocalcemia

\section{Introduction}

Thyroidectomy represents the surgical and often the curative treatment for some of the thyroid pathologies. The procedure involves the removal of the thyroid gland with the preservation of parathyroid glands. Even if the surgeon is experienced, sometimes, after surgery, the parathyroid glands are affected by vascular injuries, postoperative hematomas or the inadvertent removal of one or more parathyroid glands (1). The parathyroid glands secrete parathormone (PTH), a protein that regulates the serum calcium concentration (2). Нypocalcemia due to insufficient PTH can be asymp- tomatic or it can lead to serious cardiovascular, respiratory and neuromuscular complications, depending on the severity and the rapidity of the onset (3).

There is not an international consensus defining post-surgical hypoparathyroidism (PoSH). The British Association of Endocrine and Thyroid Surgeons defines postoperative hypocalcemia as a plasmatic calcium level less than $8.4 \mathrm{mg} / \mathrm{dl}$ in the first day after surgery. Tardive hypocalcemia is defined as calcium or vitamin $\mathrm{D}$ treatment requirement in order to maintain normal calcium levels 6 months or more after surgery (4). The PoSH can be characterized by the presence of hypocalcemia 
associated with a low or an inadequate normal level of parathyroid hormone (PTH) after neck surgery (5).

According to the Rochester Epidemiology Project, the prevalence of hypoparathyroidism in the population of Olmsted County, Minnesota was 37/ 100.000 people. The main cause of hypoparathyroidism was neck surgery (78\%) with a prevalence of 29/ 100.000 people. In U.S.A. approximately 115.000 people suffer from hypoparathyroidism, with a mean age of $58 \pm 20$ years, $71 \%$ being women (6). In Denmark, Underbjerg L. et al reported an estimated prevalence of hypoparathyroidism after neck surgery of $22 / 100.000$ and a prevalence of nonsurgical cases of 2.3/ 1.000.000 $(7,8)$. The percentage of hypoparathyroidism after neck surgery differed according to the pathology for which the surgery was performed, as follows: $33 \%$ in thyroid cancer, $33 \%$ in multinodular goiter and $10 \%$ in primary hyperparathyroidism (7). The transient PoSH, defined as hypoparathyroidism which lasts less than 6 months, affects 25.4 - 83\% of patients after neck surgery worldwide, in contrast with permanent PoSH, defined as hypoparathyroidism which lasts more than 6 months, which affects $0.12-4.6 \%$ of patients $(9,10)$.

There are both modifiable and nonmodifiable risk factors for PoSH that can be related to patients, their disease or the type of surgery performed, such as: low preoperative calcium, magnesium and vitamin D levels (1114), autoimmune thyroid disease, retrosternal nodular goiter, lack of an experienced surgical team (5), the surgical technique (13), the correct visualization of the parathyroid glands $(15,16)$ and the number of viable parathyroid glands that remain after surgery (5), lymphadenectomy for thyroid cancer or re-operation.

The aim of this study was to investigate the prevalence of PoSH and to identify patient and disease related factors associated with postoperative hypocalcemia.

\section{Materials and Methods}

\section{Patients and study protocol}

We retrospectively analyzed the files of 586 patients who underwent thyroidectomy in our surgery department between 2015-2017 with the aim to assess the prevalence of PoSH and to identify patient and disease related factors associated with postoperative hypocalcemia. Inclusion criteria: total thyroidectomy $(n=552)$, presence of PoSH defined as serum calcium levels below $8.4 \mathrm{mg} / \mathrm{dl}$ in the first day after the surgery $(n=190)$. Exclusion criteria: unilateral thyroid lobectomy $(\mathrm{n}=34)$, no calcium level evaluation before surgery $(n=17)$ and low serum calcium levels before surgery $(n=2)$. Studied patients with PoSH ( $n=171)$ were compared to 39 age, sex and BMI matched control patients that did not develop PoSH (Fig. 1).

We assessed a total of 210 patients, 187 women (89\%), with a median age of 49 , range 20- 82 years. The pathological diagnoses were: multinodular goiter (113, 53.8\%), thyroid carcinoma (68, 32.4\%) and Graves' disease (29,

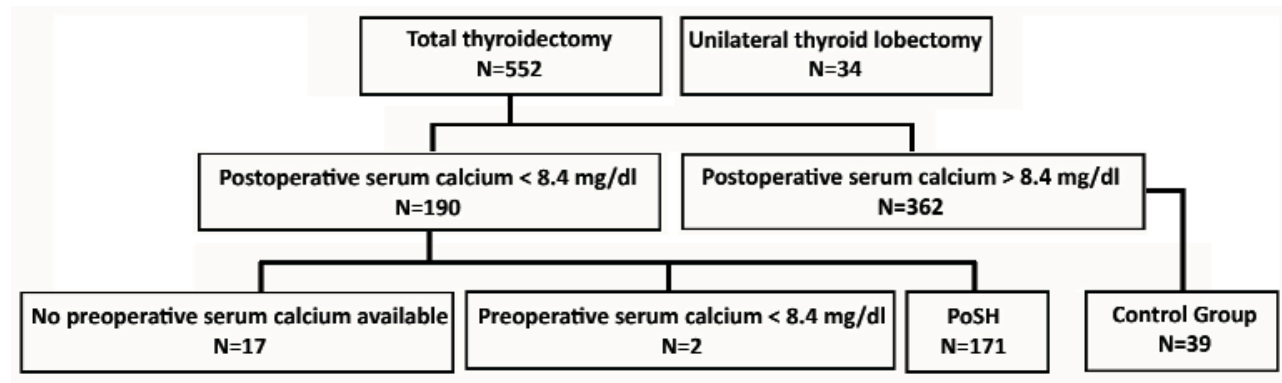

Figure 1. Study design 
13.8\%). Data collected from medical files were: personal and family history, age, gender, anthropometric measurements (weight, height, BMI), the thyroid disease that recommended the thyroidectomy, laboratory findings before surgery [serum calcium, PTH, 25 hydroxyvitamin $\mathrm{D}$, phosphorus, magnesium, alkaline phosphatase, glycemia, creatinine, TSH, FT4, anti-thyroid peroxidase antibodies (TPOAb) levels], imagistic data before surgery (ultrasound measurement of the thyroid lobes), intraoperative data (duration of the surgical intervention, neck dissection, retrosternal goiter extension, surgical reintervention and surgeon reported difficult thyroidectomy), pathological data (thyroid lobe measurement, dominant nodule maximum diameter, the presence of parathyroid tissue, anatomopathological diagnosis), laboratory findings the first day after surgery (serum calcium, serum calcium decline- calculated as the difference between preoperative serum calcium and first day postoperative serum calcium), calcium and vitamin $\mathrm{D}$ treatment at discharge, and long term follow-up data, at least 6 weeks after surgery (long term serum calcium- calculated as the mean serum calcium level of all the available samplings measured from the sixth week after surgical intervention until last check up, hypocalcemia duration- calculated from the surgical intervention until the first sampling of a normal serum calcium level, dosages of calcium, vitamin $\mathrm{D}$ and treatment duration). Transient PoSH was defined as hypoparathyroidism lasting $<6$ months. The reference values for the studied serum parameters were: calcium $=$ 8.4- $10.2 \mathrm{mg} / \mathrm{dL}, \mathrm{PTH}=15^{-65} \mathrm{pg} / \mathrm{mL}, 2^{-}$ hydroxyvitamin $\mathrm{D}=<20$ (deficit), $20-30 \mathrm{ng} /$ $\mathrm{mL}$ (insufficient), 30-100 ng/ mL (optimum), phosphorus $=2.5-4.5 \mathrm{mg} / \mathrm{dL}$, magnesium $=$ $1.6^{-} 2.6 \mathrm{mg} / \mathrm{dL}$, alkaline phosphatase $=40^{-}$ $150 \mathrm{U} / \mathrm{L}, \mathrm{TSH}=0.4-4 \mu \mathrm{UI} / \mathrm{mL}, \mathrm{FT} 4=0.89-$ $1.76 \mathrm{ng} / \mathrm{dL}, \mathrm{TPOAb}=5-35 \mathrm{UI} / \mathrm{L}$.

\section{Data Presentation and Statistical Analyses}

Descriptive data are presented as means $\pm \mathrm{SD}$, medians with interquartile range (IQR) or percentages. Shapiro-Wilk test was used to assess the normality of data distribution. Between- groups comparisons were carried out using parametric (independent sample $\mathrm{t}$ - test, one - way ANOVA) or nonparametric (Mann- Whitney U- test, Kruskal- Wallis one - way ANOVA) tests, as appropriate. Chi square test and Fisher's exact test were used to compare proportions in large and small groups, respectively. Relations between continuous variables were analyzed using Pearson's correlation parametric coefficient or Spearman's Rho nonparametric correlation coefficient. The SPSS statistical package for Windows, version 20.0. (IBM Corp. Released 2011. IBM SPSS Statistics for Windows, Version 20.0. Armonk, NY: IBM Corp.), was used to perform all statistical analysis. A $p$ value $<0.05$ indicated statistical significance.

\section{Results}

A total number of 171 patients, 153 women (89.5\%), median (IQR) age 49 (22) years, developed hypocalcemia the first day after surgery, rendering the prevalence of PoSH to $30.97 \%$, out of which $88.37 \%$ was transient and $11.63 \%$ permanent.

Demographic, clinical and preoperative laboratory findings of the 171 patients with PoSH were not significantly different when compared to 39 age, sex and BMI matched controls that did not develop PoSH after total thyroidectomy, except the median preoperative serum magnesium level that was significantly higher in $\mathrm{PoSH}$ group compared to controls [2.04 (0.17) vs $1.89(0.28) \mathrm{mg} / \mathrm{dl}, \mathrm{p}=0.005]$ (Table 1). In PoSH group, although, all the other preoperative biological parameters were similar in both genders (data not shown), median serum magnesium [2.04 (0.15) vs. $1.86(0.36) \mathrm{mg} / \mathrm{dl}$, $\mathrm{p}=0.031]$ and mean phosphorus levels $(4.02 \pm$ 0.47 vs $3.4 \pm 0.2 \mathrm{mg} / \mathrm{dl}, \mathrm{p}=0.031)$ were significantly higher in women compared to males.

First day postoperative median serum calcium levels [7.9 (0.6) vs $8.8(0.5) \mathrm{mg} / \mathrm{dl}$, $\mathrm{p}<0.001$ ] (Fig. 2) and long term follow-up serum calcium levels [9 $(0.78) \mathrm{mg} / \mathrm{dl}$ vs. 9.55 (0.4) $\mathrm{mg} / \mathrm{dl}, \mathrm{p}<0.001]$, were significantly lower 
Table 1. Demographic, clinical and preoperative laboratory characteristics of the 171 patients with PoSH compared to the age, sex and BMI matched controls

\begin{tabular}{|c|c|c|c|}
\hline Parameter & $\begin{array}{l}\text { PoSH group } \\
(\mathrm{N}=171)\end{array}$ & $\begin{array}{l}\text { Control group } \\
(\mathrm{N}=39)\end{array}$ & $P$ value \\
\hline \multicolumn{4}{|l|}{ Gender - N, (\%) } \\
\hline Female & $153(89.5 \%)$ & $34(87.2 \%)$ & 0.77 \\
\hline Male & $18(10.5 \%)$ & $5(12.8 \%)$ & 0.43 \\
\hline Age - median (IQR) (years) & $49(22)$ & $49(21)$ & 0.64 \\
\hline $\mathrm{BMI}$ - median (IQR) $(\mathrm{kg} / \mathrm{m} 2)$ & $28.15(7.3)$ & $27.92(6.83)$ & 0.79 \\
\hline Serum calcium - mean \pm SD $(\mathrm{mg} / \mathrm{dl})$ & $9.48 \pm 0.41$ & $9.57 \pm 0.36$ & 0.20 \\
\hline Serum phosphorus - mean \pm SD $(\mathrm{mg} / \mathrm{dl})$ & $3.97 \pm 0.48$ & $3.81 \pm 0.36$ & 0.38 \\
\hline Serum magnesium - median (IQR) (mg/dl) & $2.04(0.17)$ & $1.89(0.28)$ & 0.005 \\
\hline Alkaline phosphatase - median (IQR) (U/I) & $74(32.5)$ & $67(26)$ & 0.88 \\
\hline Creatinine - median (IQR) $(\mathrm{mg} / \mathrm{dl})$ & $0.73(0.12)$ & $0.72(0.13)$ & 0.84 \\
\hline PTH - mean \pm SD $(\mathrm{pg} / \mathrm{ml})$ & $58.69 \pm 18.42$ & $43.86 \pm 13.61$ & 0.30 \\
\hline 25-hydroxyvitamin D - mean \pm SD (ng/ml) & $22.73 \pm 11.04$ & $23.59 \pm 9.60$ & 0.89 \\
\hline TSH - median $(\mathrm{IQR})(\mu \mathrm{Ul} / \mathrm{ml})$ & $0.83(1.85)$ & $1.23(2.26)$ & 0.43 \\
\hline FT4 - median (IQR) (ng/dl) & $1.04(0.27)$ & $1.07(0.34)$ & 0.60 \\
\hline TPOAb - median (IQR) (Ul/ml) & $12(101.57)$ & $10(0.75)$ & 0.20 \\
\hline
\end{tabular}

in PoSH group compared to controls. The mean serum calcium decline after thyroidectomy was significantly higher in PoSH group compared to controls $(1.72 \pm 0.57$ vs $0.74 \pm 0.44$ $\mathrm{mg} / \mathrm{dl}, \mathrm{p}<0.001)$. When analyzing all the 210 patients studied, serum calcium decline was positively correlated to the duration of the surgical intervention $(\mathrm{r}=0.166, \mathrm{p}=0.027)$. We found no other significant difference between first day postostoperative biological parameters, surgical and pathology reports data in PoSH patients compared to the control group

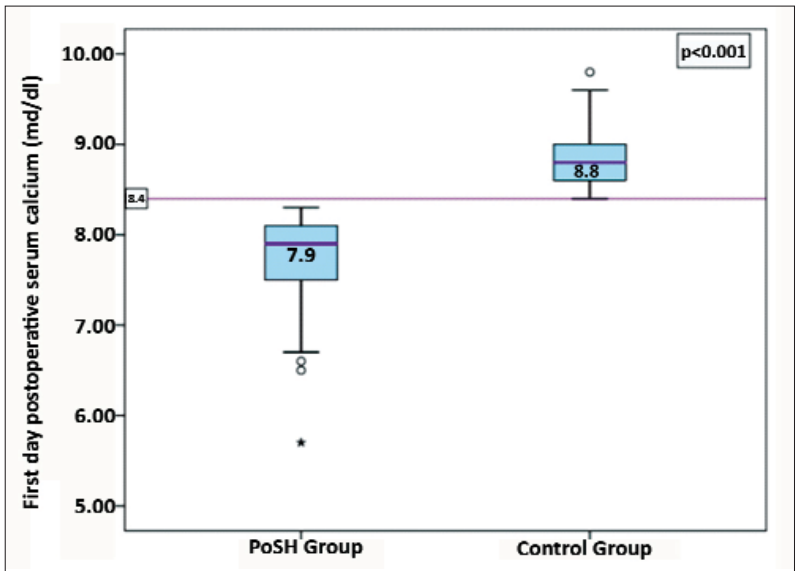

Figure 2. The median first day postoperative serum calcium levels in PoSH patients compared to the control group
(Table 2).

Although, all the other postoperative biological, surgical and pathological parameters were similar in both genders (data not shown), in the PoSH group, the median surgical intervention time was significantly longer in males compared to females [160 (78) vs. 130 (52) minutes, $\mathrm{p}=0.030$ ].

In the subgroup of patients with thyroid carcinoma the surgery duration was longer in PoSH patients compared to the control group [135 (60) vs. 110 (43) minutes, $p=0.020]$.

In the PoSH group, the median first day postoperative serum calcium level was significantly higher in patients with surgeon reported difficult thyroidectomy $[8.2(0.2) \mathrm{vs}$. $7.9(0.6) \mathrm{mg} / \mathrm{dl}, \mathrm{p}=0.043]$. Also, the mean serum calcium level decline was significantly higher in patients with lymph nodes cervical neck dissection compared to those without ( $1.94 \pm 0.59$ vs. $1.68 \pm 0.56 \mathrm{mg} / \mathrm{dl}, \mathrm{p}=0.033)$. Our data showed that, in patients with $\mathrm{PoSH}$, there was a weak positive correlation between age and preoperative $(\rho=0.181, p=0.018)$, respectively age and first day postoperative $(\rho=0.260, \quad p=0.001)$ serum calcium levels. Furthermore, first day postoperative serum calcium levels were positively correlated to the 
Table 2. Postostoperative biological parameters, surgical and pathology reports data in PoSH patients compared to the control group

\begin{tabular}{|c|c|c|c|}
\hline Parameter & $\begin{array}{l}\text { PoSH group } \\
(\mathrm{N}=171)\end{array}$ & $\begin{array}{c}\text { Control group } \\
(\mathrm{N}=39)\end{array}$ & $P$ value \\
\hline \multicolumn{4}{|l|}{ First day postoperative biological parameters } \\
\hline Serum calcium - median (IQR) (mg/dl) & $7.9(0.6)$ & $8.8(0.5)$ & $<0.001$ \\
\hline Serum calcium decline - mean \pm SD $(\mathrm{mg} / \mathrm{dl})$ & $1.72 \pm 0.57$ & $0.74 \pm 0.44$ & $<0.001$ \\
\hline Serum phosphorus - mean \pm SD (mg/dl) & $5.26 \pm 1.32$ & $4.26 \pm 1.07$ & 0.23 \\
\hline Serum magnesium - mean \pm SD $(\mathrm{mg} / \mathrm{dl})$ & $1.69 \pm 0.16$ & $1.60 \pm 0.07$ & 0.48 \\
\hline \multicolumn{4}{|l|}{ Surgical data } \\
\hline Surgery duration - median (IQR) (min) & $130(55)$ & $123.5(47)$ & 0.29 \\
\hline Re- operative thyroid surgery, (\%) & 2.3 & 2.6 & 1 \\
\hline Surgeon reported difficult thyroidectomy, (\%) & 8.3 & 6.2 & 1 \\
\hline Retrosternal goiter, (\%) & 7 & 2.6 & 0.47 \\
\hline Intraoperative parathyroid injury, (\%) & 0.7 & 0 & 1 \\
\hline Inadvertent excision of parathyroid tissue, (\%) & 3.5 & 5.1 & 0.64 \\
\hline Cervical neck dissection and lymphadenectomy, (\%) & 15.2 & 17.9 & 0.67 \\
\hline \multicolumn{4}{|l|}{ Pathology report data } \\
\hline Lymph node metastasis, (\%) & 68.8 & 25 & 0.25 \\
\hline Extra glandular invasion, (\%) & 38.5 & 35.7 & 0.85 \\
\hline Intrathyroidal calcifications, (\%) & 18.1 & 30.8 & 0.07 \\
\hline \multicolumn{4}{|l|}{ Thyroid disorder - histological diagnosis - N, (\%) } \\
\hline Benign & $117(68.4)$ & $25(64.1)$ & 0.60 \\
\hline Malignant & $54(31.6)$ & $14(35.9)$ & \\
\hline Chronic autoimmune thyroiditis, (\%) & 31 & 33.3 & 0.77 \\
\hline Histological thyroid volume ${ }^{*}$ - median (IQR) (ml) & $39.51(43.18)$ & $33.05(47.18)$ & 0.32 \\
\hline Maximum tumor diameter - median (IQR) (mm) & $12(20)$ & $17.5(16)$ & 0.18 \\
\hline \multicolumn{4}{|l|}{ Long-term biological parameters } \\
\hline Serum calcium - median (IQR) (mg/dl) & $9(0.78)$ & $9.55(0.4)$ & $<0.001$ \\
\hline Serum phosphorus - median (IQR) (mg/dl) & $4.12(0.91)$ & $3.7(0.77)$ & 0.18 \\
\hline PTH - mean \pm SD $(p g / m l)$ & $37.54 \pm 21.33$ & $51.13 \pm 13.49$ & 0.23 \\
\hline 25-hydroxyvitamin D - mean \pm SD $(\mathrm{ng} / \mathrm{ml})$ & $23.21 \pm 9$ & $22.89 \pm 2.93$ & 0.95 \\
\hline
\end{tabular}

* $\mathrm{V}(\mathrm{ml})=0.479 \times \mathrm{d} \times \mathrm{w} \times \mathrm{I}(\mathrm{cm})$ for each lobe. $(17)$

duration of hypocalcemia $(\rho=0.320, p=0.036)$ and long-term serum calcium levels were negatively correlated to the maximum diameter of the dominant thyroid nodule $(\rho=-$ 0.350, $\mathrm{p}=0.031$ ). In our PoSH patients, the time duration of postoperative hypocalcemia, defined as the time between surgery and the first normal serum calcium level, varied between 30 to 365 days, with a median of 60 (67.5) days.

\section{Discussions}

In adults, the most common cause of acquired hypoparathyroidism is surgery, constituting
$75 \%$ of all cases (18). Postsurgical hypoparathyroidism can occur after thyroid, parathyroid or radical neck surgery for head and neck cancer, and it may be transient, with recovery in days to months, permanent or even intermittent, due to decreased parathyroid reserve. Serum calcium and albumin should be monitored in the evening of surgery and the next morning after near- total or total thyroidectomy. The reported incidence of postsurgical hypocalcaemia varies significantly in the literature, the variation thought to be partly due to differences in the definitions used. Our study showed that the prevalence of PoSH was $30.97 \%$ (88.37\% transient, $11.63 \%$ 
permanent) and the median (IQR) duration of postoperative hypocalcemia was 60 (67.5) days, consistent with data provided by other observational studies and the meta-analysis published by Edafe et al., which reported a PoSH prevalence of $28 \%$ (13).

Hypoparathyroidism occurs particularly when the goiter is extensive and anatomic landmarks are displaced and obscured during surgery. In our PoSH group, the main thyroid disorders for which thyroidectomy was recommended were: multinodular goiter (53.8\%), thyroid carcinoma (32.4\%) and Graves' disease (13.8\%), similar with recently published data by Galy- Bernadoi et al (19).

In patients with hypoparathyroidism the main biochemical finding is hypocalcemia with a low or inappropriately normal serum PTH level. In addition, most patients with hypoparathyroidism have an elevated serum phosphorus level, usually normal serum 25-hydroxyvitamin $\mathrm{D}$, normal or low $1,25^{-}$ dihydroxyvitamin D concentrations and normal magnesium and creatinine levels.

As previously reported by Edafe et al., we found no difference between preoperative serum calcium levels in PoSH patients compared to controls. Furthermore, our results showed that PoSH patients had a sharper fall in serum calcium levels than controls after operation, which is in accordance with the results published by Walsh et al (20). Regarding preoperative PTH levels, correlative to the results of Brophy et al., we found no difference between patients with PoSH and controls (21). Some authors highlighted the importance of postoperative PTH measurements and the fact that a postoperative PTH fall could predict the development of $\mathrm{PoSH}$ $(22,23)$. Unfortunately, in our retrospective study postoperative PTH levels were not consistently available. Preoperative 25 hydroxyvitamin D levels were not significantly different in PoSH patients compared to controls, consistent with the prospective study of Lee et al. that found no correlation between postoperative serum calcium levels and preoperative serum vitamin D levels, and stated that postoperative serum calcium levels were similar in vitamin D deficit patients vs normal vitamin D group (24). Despite this, it appears reasonable to screen for vitamin D deficiency in patients undergoing thyroid surgery as part of preoperative workup and treat them appropriately in order to reduce both incidence and severity of postoperative hypocalcaemia (1). Our results showed that preoperative serum magnesium levels were significantly higher in PoSH group compared to controls and postoperative serum magnesium levels were not different in the two groups. Other studies have also found no association between postoperative serum magnesium and post-thyroidectomy hypocalcaemia $(25,26)$. In contrast, Brophy et al. found similar preoperative serum magnesium levels in both groups, but lower postoperative serum magnesium levels in patients with PoSH (21). The differences between these studies may be attributed, in our case, to the smaller number of patients with measured postoperative serum magnesium. Miah et al. found a high preoperative serum alkaline phosphatase in patients with postoperative hypocalcemia, not sustained by our data that showed similar preoperative serum alkaline phosphatase in the two groups (27). Regarding the preoperative serum creatinine, thyroid hormones and serum phosphorus, in line with previous data from Edafe et al. (13), we found no significant differences between the two groups analyzed.

Factors such as surgical technique, use of specific hemostatic techniques and parathyroid imaging are considered preventive measures, while several surgical factors may help in predicting the risk of PoSH. All our surgical (surgery duration, re-operative thyroid surgery, surgeon reported difficult thyroidectomy, retrosternal goiter, intraoperative parathyroid injury, inadvertent excision of parathyroid tissue, cervical neck dissection and lymphadenectomy) and pathology reports (lymph node metastasis, extra- glandular invasion, intrathyroidal calcifications, histological diagnosis, chronic autoimmune thyroiditis, histological thyroid volume, maximum tumor diameter) data investigated were similar in the two groups, in contrast to the results from Edafe et 
al., which highlights the importance of these parameters in PoSH onset (13). Yet, in our 171 PoSH patients, the median first day postoperative serum calcium level was significantly higher in patients with surgeon reported difficult thyroidectomy that might be attributed to increased attention paid by the surgeon in difficult operations. The need for a prophylactic central compartment lymph node dissection remains a controversial issue in the management of patients with thyroid cancer without clinical or radiological evidence of cervical lymphadenopathy, the primary concern being the increased incidence of hypoparathyroidism (28). Our study confirmed that mean serum calcium level decline was significantly higher in patients with lymph nodes cervical neck dissection compared to those without. In the subgroup of patients with thyroid carcinoma the surgery duration was longer in PoSH patients compared to the control group corresponding to the results of Lang et al (29). Younger PoSH patients presented lower preoperative and first day postoperative serum calcium levels. Furthermore, patients with shorter duration of hypocalcemia had lower first day postoperative serum calcium levels and long-term serum calcium levels were lower in patients with larger thyroid nodules.

Our study has some strengths as well as several limitations. Although we have addressed an important and frequent complication of thyroidectomy and we have studied a relatively large population of PoSH patients, we cannot exclude that we could have missed associations of smaller magnitude due to low statistical power. Another limitation is the retrospective nature of the study that led to important missing data.

\section{Conflict of Interest}

The authors declare no conflicts of interests.

\section{Conclusion}

In conclusion, our data show a $30.97 \%$ prevalence of PoSH, mostly transient, prevalence that is likely to increase given the rising number of thyroid surgeries being performed. Further research is needed in order to better define this condition, to establish appropriate treatment and preventive measures.

\section{Compliance with Ethical Standard}

The study protocol was approved by the ethics committee of the Elias Hospital. The study was conducted according to the standards of good clinical practice and the Declaration of Helsinki and all study patients signed an informed consent.

\section{Conflicts of Interest}

The authors declare that they have no conflict of interest

\section{References}

1. Edafe 0 , Balasubramanian SP. Incidence, prevalence and risk factors for post-surgical hypocalcaemia and hypoparathyroidism. Gland Surg. 2017;6(Suppl 1):S59-S68.

2. Shoback D, Sellmeyer D, Bikle D. Chapter 8. Metabolic Bone Disease. In: Gardner DG, Shoback D, Greenspan's Basic \& Clinical Endocrinology. 9th ed. The McGraw-Hill Companies; 2011:227-241.

3. Khan MI, Waguespack SG, Hu MI. Medical management of postsurgical hypoparathyroidism. Endocrine Practice: Official Journal of the American College of Endocrinology and the American Association of Clinical Endocrinologists. 2011;17 Suppl 1:18-25.

4. Chadwick D. The British association of endocrine and thyroid surgeons, fifth national audit report. Oxfordshire: Dendrite Clinical Systems, 2017

5. Shoback DM, Bilezikian JP, Costa AG, Dempster D, Dralle H, Khan $A A$, et al. Presentation of Hypoparathyroidism: Etiologies and Clinical Features. J Clin Endocrinol Metab. 2016;101(6):2300-12.

6. Clarke BL, Leibson C, Emerson J, Ransom J, Lagast H. Co-morbidmedical conditions associated with prevalent hypoparathyroidism: a population-based study. J Bone Miner Res. 2011;26:S182.

7. Underbjerg L, Sikjaer T, Mosekilde L, Rejnmark L. Cardiovascular and renal complications to postsurgical hypoparathyroidism: A Danish nationwide controlled historic follow-up study. J Bone Miner Res. 2013;28(11):2277-2285.

8. Underbjerg L, Sikjaer T, Mosekilde L, Rejnmark L. The Epidemiology of Nonsurgical Hypoparathyroidism in Denmark: A Nationwide Case Finding Study. J Bone Miner Res. 2015;30(9):1738-1744.

9. Page C, Strunski V. Parathyroid risk in total thyroidectomy for bilateral, benign, multinodular goitre: report of 351 surgical cases. J Laryngol Otol. 2007;121(03):237-241.

10. Asari R, Passler C, Kaczirek K, Scheuba C, Niederle B. Hypoparathyroidism After Total Thyroidectomy. Arch Surg. 2008; 143(2):132.

11. Griffin TP, Murphy MS, Sheahan P. Vitamin D and Risk of Postoperative Hypocalcemia After Total Thyroidectomy. JAMA Otolaryngol Head Neck Surg. 2014;140(4):346.

12. Bergenfelz A, Jansson S, Kristoffersson A, et al. Complications to thyroid surgery: results as reported in a database from a multicenter audit comprising 3,660 patients. Langenbecks Arch Surg. 2008;393(5):667-673.

13. Edafe 0, Antakia R, Laskar N, Uttley L, Balasubramanian SP. Systematic review and meta-analysis of predictors of post- 
thyroidectomy hypocalcaemia. Br J Surg. 2014;101(4):307-320.

14. Garrahy A, Murphy MS, Sheahan P. Impact of postoperative magnesium levels on early hypocalcemia and permanent hypoparathyroidism after thyroidectomy. Head Neck. 2016;38(4):613-619.

15. Thomusch O, Machens A, Sekulla C, Ukkat J, Brauckhoff M, Dralle $H$. The impact of surgical technique on postoperative hypoparathyroidism in bilateral thyroid surgery: A multivariate analysis of 5846 consecutive patients. Surgery. 2003;133(2):180-185

16. Praženica P, O'Keeffe L, Holý R. Dissection and identification of parathyroid glands during thyroidectomy: Association with hypocalcemia. Head Neck. 2015;37(3):393-399.

17. Brunn J, Block U, Ruf G, Bos I, Kunze WP, Scriba PC. Volumetric analysis of thyroid lobes by real-time ultrasound (author's transl). Dtsch Med Wochenschr. 1981;106(41):1338-1340.

18. Hakami Y, Khan A. Hypoparathyroidism. Front Horm Res. 2019;51: 109-126.

19. Galy-Bernadoy C, Lallemant B, Chambon G, Pham HT, Reynaud C, Alovisetti $\mathrm{C}$, et al. Parathyroid Hormone Assays following Total Thyroidectomy: Is There a Predictive Value? Eur Thyroid J. 2018; 7(1):34-38.

20. Walsh SR, Kumar B, Coveney EC. Serum calcium slope predicts hypocalcaemia following thyroid surgery. Int J Surg. 2007;5(1):41-44.

21. Brophy C, Woods R, Murphy MS, Sheahan P. Perioperative magnesium levels in total thyroidectomy and relationship to hypocalcemia. Head Neck. 2019;41(6):1713-1718.

22. Lecerf P, Orry D, Perrodeau E, et al. Parathyroid hormone decline 4 hours after total thyroidectomy accurately predicts hypocalcemia. Surgery. 2012;152(5):863-868.

23. Schlottmann F, Arbulú AL, Sadava EE, Mendez P, Pereyra L, Fernández Vila JM, et al. Algorithm for early discharge after total thyroidectomy using PTH to predict hypocalcemia: prospective study. Langenbecks Arch Surg. 2015;400(7): 831-836.

24. Lee GH, Ku YH, Kim H II, Lee M-C, Kim MJ. Vitamin D level is not a predictor of hypocalcemia after total thyroidectomy. Langenbecks Arch Surg. 2015;400(5):617-622.

25. Cavicchi 0, Piccin 0, Caliceti U, et al. Accuracy of PTH assay and corrected calcium in early prediction of hypoparathyroidism after thyroid surgery. Otolaryngol Gland Surg 2017;6(Suppl 1):S59-S68

26. Wu SD, Gao L. Is routine calcium supplementation necessary in patients undergoing total thyroidectomy plus neck dissection? Surg Today 2011:41:183-8.

27. Miah MS, Mahendran S, Mak C, Leese G, Smith D. Pre-operative serum alkaline phosphatase as a predictive indicator of postoperative hypocalcaemia in patients undergoing total thyroidectomy. $\mathrm{J}$ Laryngol Otol. 2015;129(11):1128-1132.

28. Mitra I, Nichani JR, Yap B, Homer JJ 2011 Effect of central compartment neck dissection on hypocalcaemia incidence after total thyroidectomy for carcinoma. J Laryngol Otol 125:497-501.

29. Lang BH-H, Yih PC-L, Ng KK. A prospective evaluation of quick intraoperative parathyroid hormone assay at the time of skin closure in predicting clinically relevant hypocalcemia after thyroidectomy. World J Surg. 2012;36(6):1300-1306. 